\title{
Using technology for formative assessment in food preservation learning
}

\author{
Nani Yuliani*, Yatti Sugiarti, \& Dwi Lestari Rahayu \\ Fakultas Pendidikan Teknologi dan Kejuruan, Universitas Pendidikan Indonesia \\ Jl. Dr. Setiabudhi No. 207, Bandung, 40154, Indonesia \\ *Corresponding Author. e-mail: naniyuliani@student.upi.edu
}

\begin{abstract}
The research aims to determine the cognitive and affective aspects of learning outcomes on food preservation learning that applies formative assessment using Plickers app. The study used quasi experimental method with non equivalent control group design. The research sample consisted of 22 students as an experimental class and 22 students as a control class. Measurement of learning outcomes of cognitive aspects was based on the reults of the pretest and posttest. Measurement of learning outcomes for affective aspects was based on the results of assessment of indicators of visual, verbal, listening, drawing, writing, motor, mental, and emotional activity. The results showed that the experimental group that implemented formative assessment using the Plickers app had cognitive learning outcomes better than the control class. The average score of the $\mathrm{N}$-Gain experiment class was 0.486 (in the medium category), while the control class was 0,266 (in the low category). The average results of the indicators assessment of affective aspects on the experiment class was in a very good category whereas the control class was in a good category. Applying formative assessments with the Plickers app not only provides assessments but also increases student learning activities and involvement in the learning process.
\end{abstract}

Keywords: formative assessment, Plickers, affective aspects, cognitive aspects, improve learning, online tools

\section{Penilaian formatif menggunakan teknologi pada materi pengawetan bahan pangan}

\begin{abstract}
Abstrak
Penelitian ini bertujuan untuk mengetahui hasil belajar pada aspek kognitif dan afektif siswa pada pembelajaran materi pengawetan bahan pangan yang menerapkan formative assessment menggunakan aplikasi Plickers. Penelitian menggunakan quasi experimental method dengan non equivalent control group design. Sampel penelitian terdiri dari 22 siswa sebagai kelas eksperimen dan 22 siswa sebagai kelas kontrol. Pengukuran hasil belajar aspek kognitif dilakukan berdasarkan hasil pre-test dan post-test. Pengukuran hasil belajar aspek afektif didasarkan pada hasil penilaian indikator aktivitas visual, lisan, mendengarkan, menggambar, menulis, motorik, mental, dan emosional. Hasil penelitian menunjukkan bahwa kelas eksperimen yang menerapkan formative assessment menggunakan aplikasi Plickers memiliki hasil belajar pada aspek kognitif yang lebih baik dari kelas kontrol. Nilai rata-rata N-Gain kelas eksperimen adalah 0,486 (kategori sedang) sedangkan pada kelas kontrol adalah 0,266 (kategori rendah). Rata-rata penilaian indikator hasil belajar aspek afektif kelas eksperimen berada pada kategori sangat baik sedangkan kelas kontrol berada pada kategori baik. Penerapan penilaian formatif dengan aplikasi selain memberikan penilaian juga meningkatkan aktivitas belajar dan keterlibatan siswa.
\end{abstract}

Kata Kunci: penilaian formatif, Plickers, aspek afektif, aspek kognitif, pembelajaran, perangkat online

How to Cite: Yuliani, N., Sugiarti, Y., \& Rahayu, D. L. (2020). Using technology for formative assessment in food preservation learning. Jurnal Penelitian Ilmu Pendidikan, 13(2), 110-119. doi: https://doi.org/10.21831/jpipfip.v13i2.32555

Received 26-06-2020; Received in revised from 27-06-2020; Accepted 10-07-2020

This is an open-access article under the CC-BY-SA license. 


\section{INTRODUCTION}

Basic processing of agricultural product (DPPHP) is one of material subjects that is must be learned by students in Agribusiness of Agricultural Product Processing Vocational Schools. DPPHP contains several basic materials which are very important and must be mastered by students as basic knowledge before they learn other productive material subjects. One of the materials in DPPHP subjects is food preservation. The material is a basic knowledge that applied in all processing practices of food product developed by SMKN 1 Pacet such as yogurt, lung chips and bandrek. Therefore, the mastery of food preservation material by students is very necessary.

Based on interviewes with DPPHP subject teachers at SMKN 1 Pacet and observations when researcher was in school apprenticeship programme, it was difficult for teachers to sorting out wich materials has been understood and not yet by students after every materials lerarning process completed. The teacher often needs one more class meeting to review the previous material, so that the time for learning process is considered less effective. Furthermore, the assessment of student learning outcomes has not yet provide an opportunity for students to recognize directly which learning outcomes they had achieved and not.

Teachers of SMKN 1 Pacet also have another challenge to teach students more attractive because of one week block system. In one week block system, normative and productive material subjects are delivered alternately every one week. Material subjects for two weeks in common schedule are delivered to students in one weeks. Those study condition tends to be the cause of monotony sense in students and overwhelmed in learning if the teacher does not convey the subject matter appropriately and attractively.

To provide an opportunity for students to improve their learning process and mastery every competency they learn, assessments that are appropriate to their function need to be applied in the learning process. Assessment according to Harlen (2007) is the process of collecting, interpreting, and using evidence to make decisions about student achievement in education. One form of learning assessment that provides feedback as well as skills to assess themselves to provide opportunities for students to improve their learning process is formative assessment (Dunn \& Mulvenon, 2009).

In this research, formative assessment by prioritizing feedback aspects was applied to make students focus during the learning process and help students achieved good learning outcomes. Guided inquiry model with STEM approach and formative assessment assisted by informative technology was used for improving students' understanding of learning material and increasing student enthusiasm in learning. The information technology is expected to make the learning process more attractive (Ningrum, 2017). One of information technology that can be used to carry out formative assessment is Plickers because the application can help the assessment process well (Francisca, 2016).

Plickers is a tool developed for teachers to provide assessments and collect assessment data in real-time by creating a pleasant atmosphere (Roifah, 2017). Plickers assists teachers to provide assessments in the form of multiple-choice using code cards. Teachers can download the Plickers application with a smartphone and use a laptop to open the Plickers.com website so they can display live broadcasts of students' questions and answers. These tools are designed very atracting to create a new atmosphere in the learning process.

Based on the description above, the aim of this research is to find out the student learning outcomes on cognitive and affective aspects in learning food preservation material by implementing formative assessment using Plickers application.

\section{METHOD}

This research is a quantitative approach research with quasi experimental method. The research design used in this study is nonequivalent control group design conducted during one class meeting. The design includes pretest and posttest as well as the control and experiment groups. The experimental group is a learning group using formative assessment with the Plickers application, while the control group is a group that does not use formative assessment with the Plickers 


\section{Jurnal Penelitian Ilmu Pendidikan, 13 (2), 2020 - 112 \\ Yuliani, Sugiarti, \& Rahayu}

application. The pretest is done to determine the initial ability of students and posttest is done to determine the direct effect of the treatment given.

Population in this study is students of SMK 1 Pacet APHP who were studying DPPHP subjects. Purposive sampling technique was used in sample choosing. The sample is student APHP class X 1 and class X Agro-industry.

The instruments used in this study include objective test instruments in the form of pretestposttest questions and quiz questions in the form of multiple choice and observation sheets of student activities to measure students' affective scores. Affective assessment indicators are in accordance with learning activities according to Paul Dierich (Hamalik, 2009) including visual activities, oral activities, listening activities, drawing activities, writing activities, motor activities, mental activities, and emotional activities. The instruments in this study were validated before being used for research data collection.

Data analysis was performed by calculating the scores achieved from all aspects assessed, both the validation of material experts, observation of student activities and the pretest-posttest used during the learning process. Data analysis techniques are performed as follows:

\section{Analysis of Observation Results}

Observations in this study were conducted to determine student learning activities during the learning activities that are taking place by filling each item on the observation sheet by scoring using a Likert scale namely 4 (Very Active), 3 (Active), 2 (Less Active) and 1 (Very Less Active)) After that, the percentage of student activity can be calculated by the following formula:

$$
\text { Student Activity }=\frac{\text { Total Score }}{\text { Maximum Score }} \times 100 \%
$$

Analysis of data from student activities obtained then converted according to Table 1 to determine the categorization of the results.

Table 1. Student Activity Categories

\begin{tabular}{ccc}
\hline No & $\begin{array}{c}\text { Persentase } \\
(\%)\end{array}$ & Kategori \\
\hline 1 & $80<\mathrm{X} \leq 100$ & Very Good \\
2 & $60<\mathrm{X} \leq 80$ & Good \\
2 & $40<\mathrm{X} \leq 60$ & Pretty Good \\
3 & $20<\mathrm{X} \leq 40$ & Not good \\
4 & $0<\mathrm{X} \leq 20$ & Not Very Good \\
\hline
\end{tabular}

(Widoyoko, 2014)

2. Analysis of Learning Outcomes Tests

Average and $\mathrm{N}$-Gain calculation

Student grades and average grades are obtained using the following formula:

$$
\begin{gathered}
\text { Student Score }=\frac{\text { Score obtained by students }}{\text { Maximum Score }} \times 100 \% \\
\bar{x} \text { (Average Value) }=\frac{\text { number of values }}{\text { lots of data }}
\end{gathered}
$$

To determine the categorization of learning outcomes, the average value obtained is converted according to Table 2 . 
Jurnal Penelitian Ilmu Pendidikan, 13 (2), 2020 - 113

Yuliani, Sugiarti, \& Rahayu

Tabel 2. Criteria For Student Learning Outcomes

\begin{tabular}{cc}
\hline Nilai rata-rata & Kriteria \\
\hline$\geq 80$ & Very Good \\
$67 \leq X<80$ & Good \\
$52 \leq X<67$ & Pretty Good \\
$38 \leq X<52$ & Not Good \\
$<38$ & Not Very Good \\
\hline \multicolumn{2}{r}{ (Syarifudin, 2010) }
\end{tabular}

For the effectiveness of improving learning outcomes can be known by using the Normalized Gain calculation, namely the following formula:

$$
\mathrm{N}-\text { Gain }=\frac{\text { post test score }- \text { pre test score }}{\text { maximum score }- \text { pre test score }}
$$

The N-Gain value scale used for the interpretation of the effectiveness of learning outcomes is shown in Table 3.

Tabel 3. Criteria Normalized Gain

\begin{tabular}{cc}
\hline Skor $N$-Gain & Kriteria $N$-Gain \\
\hline$N$-Gain $>0,70$ & High \\
$0,30<N$-Gain $\leq 0,70$ & Medium \\
$N$-Gain $\leq 0,30$ & Low \\
\hline
\end{tabular}

(Meltzer, 2002)

Hypothesis testing

Hypothesis testing with independent $t$ test can be done if the test data is normally distributed and homogeneous. Therefore, before the $t$ test is carried out, homogeneity and normality tests are first performed. Homogeneity test was done by Fisher's test (Sugiyono, 2015), while normality test is done by Kolmogorov-Smirnov test (Silalahi, et al., 2010). After the data is normally distributed and homogeneous, the test can proceed with the independent $t$ test

Parametric independent $t$ test was used to see the difference between pretest and posttest scores of the experimental and control groups. This independent $t$ test can be calculated using a formula based on Sugiyono (2015).

\section{Instrument validation}

Validation refers to the accuracy of the measuring instrument against the concept being measured, so that it truly measures what should be measured (Furchan, 2011). The instruments that went through the validation stage were the pretest-posttest questions and quiz questions conducted by DPPHP subject teachers as material experts. Validation sheets are in accordance with established guidelines according to Mulyatiningsih (2016). Based on the total score obtained, the instrument about the pretest-posttest and the quiz is feasible to use.

\section{RESULTS AND DISCUSSION}

\section{Results}

\section{Cognitive Aspects of Learning Outcomes}

The average results of the objective test assessments (pretest and posttest) and the effectiveness of increasing scores from pretest to posttest for the control class and the experimental class can be seen in Table 4.

To determine the students' initial abilities, the researchers conducted a pretest consisting of 15 questions. In Table 4, both the experimental class and the control class have average pretest scores with poor categories. After being given treatment, the researcher gave a posttest to see an increase in learning outcomes in the cognitive aspects of the experimental class and the control class. In the posttest data consisting of 15 questions, the average value of the posttest experimental class was 73.94 with a good category and a control class of 59.70 with a good category. Student learning outcomes in 
Jurnal Penelitian Ilmu Pendidikan, 13 (2), 2020 - 114

Yuliani, Sugiarti, \& Rahayu

the experimental class that achieved more KKM compared to the control class. Achievements in food preservation material showed that students who completed the experimental class reached $45.45 \%$ with a total of 10 students, while for the control class reached $22.73 \%$ with a total of 5 students. KKM that is used as a standard of success in the learning process for basic subjects in the processing of agricultural products is 80 .

Table 4. Comparison of Cognitive Assessment Results of Control Class and Experiment Class

\begin{tabular}{clccc}
\hline Class & Data & Average & Category & $\begin{array}{c}\text { Test Passess } \\
(\%)\end{array}$ \\
\hline \multirow{2}{*}{ Control } & Pretest & 44,55 & Not Good & $0 \%$ \\
& Posttest & 59,70 & Pretty Good & $22,73 \%$ \\
& N-Gain & 0,266 & Low & - \\
\hline \multirow{2}{*}{ Experiment } & Pretest & 50,00 & Not Good & $0 \%$ \\
& Posttest & 73,94 & Pretty Good & $45,45 \%$ \\
& N-Gain & 0,486 & Medium & - \\
\hline
\end{tabular}

In Table 4 the average $\mathrm{N}$-Gain results in the experimental class are included in the medium category, with an average $\mathrm{N}$-gain of 0.486 . In the control class the average $\mathrm{N}$-gain was 0.266 with the low category. The difference in the average $\mathrm{N}$-Gain from the experimental class and the control class is quite large, because both are in different categories. These results can be concluded that the average effectiveness of learning outcomes in the experimental class is higher than the control class.

To find out the differences of student learning outcomes in the cognitive aspects, then testing the hypothesis with an independent $t$ test that is preceded by a normality test and a homogeneity test is performed. It can be seen in table 5 .

Table 5. T Test Results for Pretest and Posttest

\begin{tabular}{cccc}
\hline Test & $\mathrm{T}_{\text {count }}$ & $\mathrm{t}_{\text {table }}$ & $\begin{array}{c}\text { Conclution of } \\
\text { Hypothesis }\end{array}$ \\
\hline Pretest & 1,433 & 2,082 & $\begin{array}{c}\text { Accepted } \\
\text { Not Accepted }\end{array}$ \\
\hline
\end{tabular}

Hypothesis testing is done when the data is normally distributed and homogeneous. The way to determine a hypothesis is accepted or rejected, that is if $t$-count> t-table, then Ho is rejected, and vice versa. The results of calculations in Table 5. It can be seen that the calculated data from the pretest between the control class and the experimental class is smaller than the table, so it can be stated that Ho is accepted meaning that there is no significant difference between the learning outcomes of the control class and the experimental class. Furthermore, the value of t-count in the posttest data is greater than t-table, so it can be stated that Ho is rejected or Ha is accepted, meaning that there is a significant difference between the learning outcomes of the experimental class and the control class.

\section{Affective Aspect Student Learning Outcomes}

Affective assessment is done through the measurement of student learning activities results of observation. Affective assessment includes eight indicators related to student activities during the learning process, from preliminary activities to closing activities. Indicators used as affective assessment of these students are in accordance with activities according to Paul Dierich (Hamalik, 2009), including visual activities, oral activities, listening activities, drawing activities, writing activities, motor activities, mental activities, and emotional activities. The comparison of the average student activity on each indicator can be seen in Figure 1.

The results of the affective assessment of the experimental class and control class students in Figure 1. shows that the average learning activity of the experimental class students has higher scores than the control class for all affective assessment indicators. The average value of the overall affective aspects of the experimental class students was $80.07 \%$. This value is in the very good category. In the control class, the average overall value of the affective aspects of students was $70.63 \%$ in the good category. 
Yuliani, Sugiarti, \& Rahayu

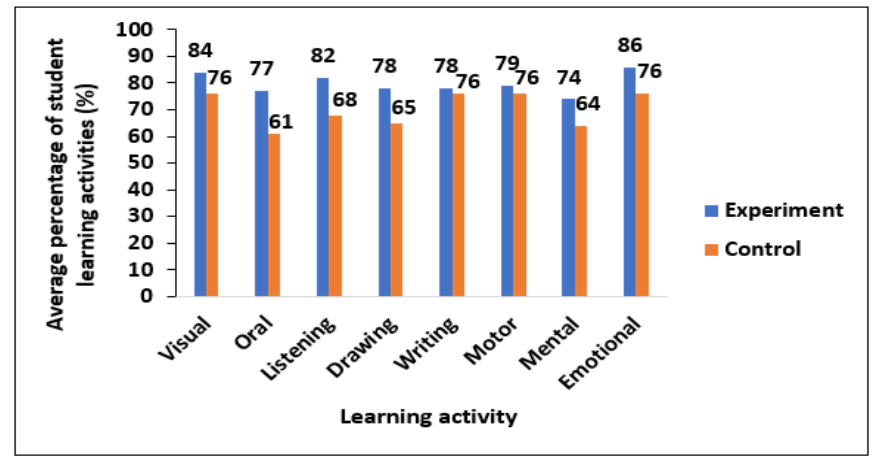

Figure 1. Student learning outcomes of experimental and control classes

Based on Figure 1, there are similarities of the five indicators namely indicators of oral activity, writing activity, drawing activity, motor activity and mental activity. The average percentage of the five activities shows that both the control class and the experimental class are in the good category. Then there are differences in indicators of visual activity, listening activity and emotional activity. In all three indicators, the experimental class is in the very good category, while the control class is in the good category.

The percentage of students who meet the affective assessment criteria in the control class and the experimental class can be seen in Figure 2.

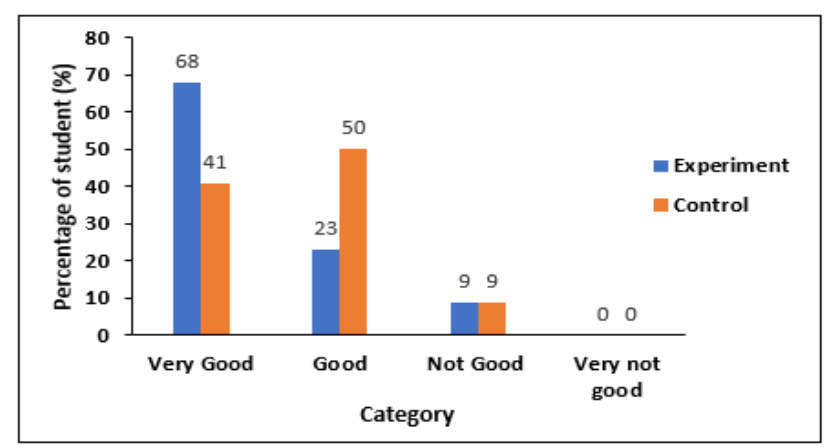

Figure 2. Comparison of student activity assessment results categories (affective aspects) during learning

Based on Figure 2, in the experimental class the highest percentage of students based on the affective assessment category is in the very good category, whereas for the control class is in the good category. This proves that the learning activities of the experimental class students are better than the control class.

\section{Discusion}

\section{Cognitive Aspects of Learning Outcomes}

Based on the posttest data results in Table 4, an increase in the average cognitive learning outcomes in the experimental class or the control class. The increase in the average posttest scores of the two classes is influenced by the use of guided inquiry models which are student-centered learning and the use of an integrated STEM approach that encourages students to learn through exploration, investigation and problem solving according to their experiences, so it is highly recommended that students are able to improve maximum learning outcomes (Asghar, Ellington, Rice, Johnson, \& Prime, 2012). According to Wasiso, Sukardi, \& Winarsih (2020), accuracy in the selection of learning models will produce quality learning and aimed at clear objectives.

The percentage of students' completeness and N-Gain value of the experimental class is superior to the control class. The difference lies in the application of formative assessment with the Plickers application in the learning process. This is consistent with research conducted by (Gloria, 
Kartimi, \& Imanah, 2018), which explains that feedback in formative assessment in general can encourage students to learn, motivate students to be more interested in the topic, improve the process and learning outcomes and lead to optimism, self-confidence and appreciation of students. The application of formative assessment with the Plickers application in the experimental class triggers students to develop their potential, compared to the control class that only uses conventional models for assessment. According to Shumway \& Harden (2003), assessment encourages students to have a strong motivation to learn and assessment is something that is considered in the community. Based on this, the use of assessments that are appropriate to their functions is needed to improve student learning outcomes.

Based on Table 4, differences in learning outcomes on the cognitive aspects of the experimental class and control class students due to the existence of different stimuli to students. The control class did not apply formative assessment with the Plickers application to learning. Formative assessment is carried out in the experimental class while learning is taking place, where the assessment process is carried out to obtain improved learning outcomes The increase in learning achievement is due to the assessment made by students themselves, between students and by the teacher to students.

Nurhasanah \& Sobandi (2016) explained that in the learning process between teachers and students are always expected to obtain good learning outcomes. However, the learning outcomes obtained by students are not always good and not always in line with expectations. Learning outcomes are influenced by the success of the learning process (Mardiana, 2015). Therefore, it is necessary to look at the level of success of the teaching and learning process to determine its impact on learning outcomes, namely by having a formative assessment. The value obtained from formative assessment is used to improve the process so that it can improve students' understanding of the material.

According to Sudjana \& Ibrahim (2010), formative assessment applied in learning helps teachers in improving the steps in learning, such as learning methods, learning models, approaches taken to provide feedback to students. Juleha, Khuzaemah, \& Cahyani (2014) added that the improvement of steps in learning is an important thing to be done by a teacher in achieving learning goals. Improvement of learning steps as a form of feedback to students can be done at the next meeting. To improve the learning process so that learning objectives can be achieved without having to use one more meeting, namely the use of the Plickers application. The use of these Plickers has made the formative assessment run well.

Implementation of formative assessment with the use of the Plickers application can provide feedback directly to teachers or students. The teacher does not have to use one more meeting to discuss material that is not yet understood by students. Feedback has many roles in the learning process because this feedback informs each stage of the process of improving learning, assessment of progress by measuring the achievement of learning targets, with this feedback the teacher is able to see the current condition of students and take the next steps to be taken in improving the learning process (Hattie \& Timperley, 2007). According to Zafri \& Yulanda (2019), who used Plickers in their research, the application of Plickers was used to help teachers convey stimulus in the form of tests to students, so that students more quickly process and respond to information provided so that the subject matter in the form of tests can be understood. With a good understanding of the material, due to the application of formative assessment using the Plickers application, the experimental class learning outcomes differ from the control class.

The t-test results in Table 5. which states the differences in the learning outcomes of the control class and the experimental class on the posttest score, indicate that the experimental class applying formative assessment with the Plickers application is able to produce more students who maximize their cognitive abilities while learning than the control class. That is because students are given feedback in the form of learning outcomes, they get from the quiz results directly. In addition, there is feedback in the form of oral feedback given by the teacher to the material that they do not yet understand, so that each student involves their abilities to the maximum. Like the opinion according to Gogri (Prisuna, 2020), "there are two interesting things from computer-based formative assessment that is able to provide instant feedback and ease the workload of teachers". In this study, the use of formative assessment with the Plickers application can provide quick feedback to students. 
Jurnal Penelitian Ilmu Pendidikan, 13 (2), 2020 - 117

Yuliani, Sugiarti, \& Rahayu

Affective Aspect Learning Outcomes

The average value of the observations of student activity from each class can be seen in Table

6.

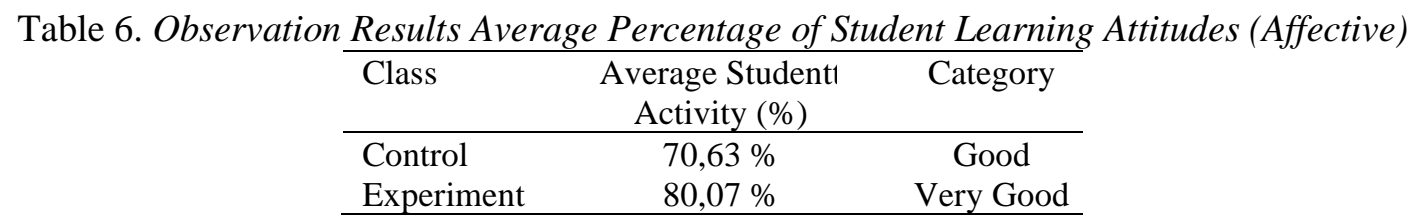

The average percentage of student learning outcomes in terms of affective aspects based on Table 6, shows that the experimental class is in the very good category, while the control class is in the good category. The average percentage of learning outcomes are obtained from observers' observations. Each observer evaluates 5-6 students from the beginning to the end of the learning process. Based on observations it appears that the learning activities of the experimental class students are better than the control class. According to Putra (2013), each student has a unique or different nature, but also has similarities, namely the steps of development and potential that need to be actualized through learning. Student learning activities of the experimental class have a superior value compared to the control class because of the many students who develop their potential due to the different stimuli given, namely the assessment using information technology. Comparison of average percentage for each indicator can be seen in Figure 1.

Based on observations on all aspects of student activity shows that the experimental class is superior to the control class. This is of course influenced by several factors, such as the readiness of teachers in teaching, the conditions when learning takes place, the accuracy of teachers in teaching, the variety of assessments used, the conditions of students and the readiness of students in receiving lessons. As according to Dimyati \& Mudjiono (2010), that the level of learning activities is influenced by internal factors found in the students themselves and the teacher who is an external factor. These factors can affect the activities carried out by students, during teaching and learning activities.

Based on Figure 2, in the experimental class, the highest percentage of students based on the affective assessment category is in the very good category, while for the control class is in the good category. This proves that the learning activities of the experimental class students are better than the control class. In the learning process that takes place by applying the feedback attributes to the formative assessment with the Plickers application in the experimental class, students emphasize the characteristics of accepting the opinions of others when discussing, caring for others and thinking about their effects on other students, being able to solve the problems given by using all of the sensory abilities to collect answers. This shows that the affective component is more widely applied in the experimental class than the control class due to an increase in student activity with more stimulus in the experimental class than the control class. In addition, according to Amrullah, Sari, \& Putri, (2017), the use of Plickers can have a positive influence on the learning process to increase student independence due to increased student enthusiasm in learning.

According to Trisnawati, Anggraeni, Waziana, \& Puspita (2019), the teacher's task is quite hard and requires accuracy in getting to know students one by one, it cannot be classically. Based on this the existence of information technology can facilitate teachers in making assessments. According to Juanos \& Ruisoto (2018), Plickers is a technology used to evaluate students in classrooms with an active methodological system, which allows teachers to analyze the knowledge acquired by students in an interesting, nimble, and dynamic way. In this study by Juanes \& Ruisoto (2018), evidence was obtained that Plickers allowed teachers to assess student knowledge through multiple choice tests with the possibility of four answers. Based on these results, one of the biggest advantages of using Plickers is that teachers can detect the students who stand out the most in their class compared to those who are slow. Therefore, researchers in this study use the Plickers application to help the process of formative assessment run well.

Formative assessment is an ongoing process that is always present in the teaching process and has the main goal in developing learning by guiding and directing learning activities in such a way as to meet the learning needs of students and make students able to manage their own learning processes (Voinea, 2018). The application of formative assessment with the Plickers application not only 
Jurnal Penelitian Ilmu Pendidikan, 13 (2), 2020 - 118

Yuliani, Sugiarti, \& Rahayu

provides assessment but also for the occurrence of the learning process so that it can increase student involvement in the process and increase student learning activities. With the increase in student learning activities have an impact on the learning process that goes well (Rusman, 2012). If the learning process takes place maximally, it is expected that the results will be maximal. According to Limpo (2013), the lack of affective assessment can be influenced by classroom environmental factors, therefore teachers need support, involvement, task orientation, cooperation, and equality to improve the characteristics of each student in a positive direction.

\section{CONCLUSION}

Based on the results of research and data analysis, it can be concluded that learning food preservation material by applying formative assessment using the Plickers application provides cognitive aspects of learning outcomes better than learning without formative assessment using Plickers. However, when viewed from the percentage of students' mastery learning at $45.45 \%$, it is still necessary to improve other learning support factors other than by implementing formative assessment using Plickers.

In the affective aspect, learning with formative assessment using Plickers shows that the average assessment of learning activity indicators is in the very good category, while learning without formative assessment using Plickers is in good category. In the eight indicators of affective aspects that are measured, emotional activity, visual, and listening are indicators that are in the best category in the class with formative assessment using Plickers.

\section{BIBLIOGRAPHY}

Amrullah, A Sari, D. K Putri, J. (2017). The impact of e-modules assisted by scaffolding based android by using Plickers on the achievement of understanding concepts and student indepedency. In Proceeding 3rd International Seminar on Science Education, 3, 93-97.

Asghar, A., Ellington, R., Rice, E., Johnson, F., \& Prime, G. M. (2012). Supporting STEM education in secondary science contexts. Interdisciplinary Journal of Problem-Based Learning, 6(2), 85125. https://doi.org/10.7771/1541-5015.1349.

Dimyati \& Mudjiono. (2006). Belajar dan pembelajaran. Jakarta: PT Rineka Cipta.

Dunn, K., \& Mulvenon, S . (2009). A critical review of research on formative assessment: The limited scientific evidence of the impact of formative assessment in education. Practical Assessment Research \& Evaluation, 14(7), 1-11. https://doi.org/10.1002/cpp.513.

Francisca, R. (2016). 15 Aplikasi yang wajib dipakai guru inovatif di tahun ajaran baru ini. Retrieved from https://life.idntimes.com/career/francisca-christy/15-aplikasi-canggih-98-yang-wajibdipakai-para-guru-inovatif-di-tahun-ajaran-baru-ini/full, at 2020-07-07, 20.55.

Furchan, H.A. (2011). Pengantar penelitian dalam pendidikan. Malang: Pustaka Pelajaran.

Gloria, R. Y., Kartimi, \& Imanah. (2018). Penerapan atribut asesmen formatif feedback pada konsep sistem reproduksi untuk membentuk habits of mind siswa kelas XI MAN 2 kota Cirebon. Jurnal Ilmu Alam Indonesia, 1(3), 135-146.

Hamalik, O. (2009). Proses belajar mengajar. Jakarta: PT. Bumi Aksara.

Harlen, W. (2007). Assessment of learning. London: Sage Publication. [Online]. Retrieved from https://books.google.co.id/books/about/Assessment_of_Learning.html?id=I4PA3O3u244C\&red ir_esc $=$ y., at 2020-07-07, 21.01.

Hattie, J., \& Timperley, H. (2007). The power of feedback. Review of Educational Research, 77(1), 81-112. https://doi.org/10.3102/003465430298487.

Juanes, J. A., \& Ruisoto, P. (2018). Technological devices for enhancing active learning. In ACM International Conference Proceeding Series, 392-396. https://doi.org/10.1145/3284179.3284246.

Juleha, S., Khuzaemah, E., \& Cahyani, D. (2014). Penerapan strategi belajar murder untuk meningkatkan penguasaan konsep siswa pada pembelajaran biologi kelas VIII MTs A-Ikhlas Setupatok Cirebon. Scientae Educatia: Jurnal Pendidikan Sains, 3(2), 95-109.

Limpo. (2013) Pengaruh lingkungan kelas terhadap sikap siswa untuk pelajaran matematika. Jurnal Humanitas, 10(1), 103-105.

Mardiana. (2015). Analisis kesesuaian instrumen penilaian autentik (autentic assessment) 
Jurnal Penelitian Ilmu Pendidikan, 13 (2), 2020 - 119

Yuliani, Sugiarti, \& Rahayu

Berdasarkan Penilaian Kurikulum 2013. (Skripsi). UIN Syarif Hidayatullah.

Meltzer, D. E. (2002). The relationship between mathematics preparation and conceptual learning gains in physics: A possible "hidden variable" in diagnostic pretest scores. American Journal of Physics, 70(12), 1259-1268. https://doi.org/10.1119/1.1514215.

Mulyatiningsih, E. (2016). Metode penelitian terapan bidang pendidikan. Bandung: Alfabeta.

Ningrum, A. S. (2017). Pengembangan model asesmen formatif berbasis inkuiri terbimbing untuk menumbuhkan self-regulation siswa SMA. Thesis. Universitas Lampung.

Nurhasanah, S., \& Sobandi, A. (2016). Minat belajar sebagai determinan hasil belajar siswa. Jurnal Pendidikan Manajemen Perkantoran, 1(1), 128-135.

Putra, S. R. (2013). Desain belajar mengajar kreatif berbasis sains. Yogyakarta: DIVA Press.

Prisuna, B. F. (2020). Pengembangan media tes fisika berbasis online untuk sekolah menengah atas. Jurnal Penelitian Ilmu Pendidikan, 13(1), 41-51.

Putri, R. D. (2020). Perbandingan kekuatan uji metode kolmogorov-smirnov, anderson-darling, dan shapiro-wilk untuk menguji normalitas data. Skripsi. Universitas Sanata Dharma.

Roifah, K. (2017). Pengaruh pemanfaatn Plickers dalam pembelajaran matematika di SMP negeri 9 Semarang terhadap motivasi dan hasil belajar siswa. Skripsi. Universitas Negeri Semarang.

Rusman. (2012). Model-model pembelajaran: Mengembangkan profesional guru. Bandung: CV Alfabeta.

Sudjana, N. \& Ibrahim, M.A. (2010). Penelitian dan penilaian pendidikan. Bandung: Sinar Baru Algensindo.

Sugiyono. (2015). Metode penelitian pendidikan, pendekatan kuantitatif, kualitatif, dan $R \& D$. Bandung: Alfabeta.

Syarifudin, B. (2010). Panduan TA keperawatan dan kebidanan dengan SPSS. Yogyakarta: Grafindo Litera Media.

Shumway, J. M., \& Harden, R. M. (2003). AMEE guide no. 25: The assessment of learning outcomes for the competent and reflective physician. Medical Teacher, 25(6), 569-584. https://doi.org/10.1080/0142159032000151907.

Trisnawati, Anggraeni, L., Waziana, W., \& Puspita, D. (2019). Evaluation of the implementation of the 2013 curriculum reviewed from the aspect of the learning process and assessment of learning outcomes. Jurnal Penelitian Ilmu Pendidikan, 12(2), 111-119.

Voinea, L. (2018). Formative assessment as assessment for learning development. Revista de Pedagogie - Journal of Pedagogy, LXVI(1), 7-23.https://doi.org/10.26755/revped/2018.1/7.

Wasiso, A. J., Sukardi, S., \& Winarsih, M. (2020). Pengaruh model pembelajaran dan sikap sosial terhadap hasil belajar sejarah siswa SMA. Jurnal Penelitian Ilmu Pendidikan, 13(1), 31-40.

Widoyoko, E. P. (2014). Teknik penyusunan instrumen penelitian. Yogyakarta: Pustaka Pelajar.

Zafri, \& Yulanda, L. (2019). Pemanfaatan aplikasi plickers pada mata pelajaran sejarah kelas X SMAN 01 IV Nagari Bayang Utara. Jurnal Kapita Selekta Geografi, 2(4), 54-77. 